Dunamis: Jurnal Teologi dan Pendidikan Kristiani

Volume 5, Nomor 1 (Oktober 2020)

ISSN 2541-3937 (print), 2541-3945 (online)

http://www.sttintheos.ac.id/e-journal/index.php/dunamis

DOI: 10.30648/dun.v5i1.330

Submitted: 4 April 2020

Accepted: 15 Juni 2020

Published: 30 September 2020

\title{
Pendidikan Kristiani di Era Post-Truth: Sebuah Perenungan Hermeneutis Paul Ricoeur
}

\author{
John C. Simon \\ STT Intim Makassar \\ tajaksebakal@gmail.com
}

\begin{abstract}
The post-truth phenomenon in the form of false news and utterances of hate actually marks an awareness that is lured to oneself (closed, rejects intersubjectivity) which causes the emergence of egological thinking. Ricoeur carries out "hermeneutics of suspicion," as a hermeneutical method, which aims to demystify arrogant subjects, which are lived out by distrust and skepticism and give birth to post-truths. The purpose of this study is to show that the perspective of education according to Ricoeur means the return of consciousness. Consciousness means unity between words and actions. It is not enough that our thoughts are good without being directly proportional to good actions. For the task of education, the unity of both is the opposite of post-truth.
\end{abstract}

Keywords: hermeneutic of suspicion; consciousness; post-truth; hate speech; hoax

\begin{abstract}
Abstrak
Fenomena post-truth berupa berita bohong dan ujaran kebencian sesungguhnya menandai kesadaran yang terpikat pada diri sendiri (tertutup, menolak intersubjektif) yang menyebabkan munculnya cari berpikir egologis. Ricoeur mengusung "hermeneutik kecurigaan" (hermeneutics of suspicion), sebagai metode hermeneutis, yang bertujuan melakukan demistifikasi atas subjek yang pongah, yang dihidupi oleh ketidakpercayaan dan skeptisisme serta melahirkan post-truth. Tujuan penelitian ini ingin memperlihatkan bahwa perspektif pendidikan menurut Ricoeur berarti kembalinya kesadaran. Kesadaran berarti satunya kata dan tindakan. Tidak cukup pikiran kita baik, tanpa berbanding lurus dengan tindakan yang baik. Bagi tugas pendidikan, maka kesatuan keduanya adalah lawan tanding bagi post-truth.
\end{abstract}

Kata Kunci: hermeneutik kecurigaan; kesadaran; pasca kebenaran; ujaran kebencian; berita bohong 


\section{PENDAHULUAN}

Salah satu aspek penting dalam perubahan masyarakat hari ini adalah euforia yang tumbuh di mana-mana untuk merespon perubahan, yaitu perubahan di mana kebohongan menjadi daya tarik. Kebohongan, apalagi yang disajikan secara sensasional dan kontroversial, bisa dianggap sebagai hal menarik. Kerumunan massa yang haus sensasi dan kontroversi adalah mangsa lezat politik di era post-truth. ${ }^{1}$ Politik posttruth itu sendiri tidak punya mata batin sehingga siapa saja dapat menjadi korbannya. Paul Ricoeur menunjukkan bahwa ideologi modern saat ini jelas pada proses rasionalisasi yang bermaksud menjinakkan wilayah tindakan intrumental dan memanipulasi "kehidupan yang baik." Praksis kehidupan adalah contohnya. Praksis tertekan dan tergencet sehingga dunia seharihari hanya semarak dengan perang katakata, wacana yang berseliweran sana-sini dan retorika tiada habisnya. Apalagi ditunjang oleh ideologi tertentu (entah basisnya sekuler atau agama), membuat upaya manipulatif itu menjelma menjadi alat

\footnotetext{
${ }^{1}$ Frieder Vogelmann, "The Problem of Post-Truth Rethinking the Relationship between Truth and Politics," BEHEMOTH A Journal on Civilisation 11, no. 2, (2018): 18-37. Aloysius Budi Kurniawan, "Menjaga Kewarasan dalam Bermedia Sosial Sejak dari Pikiran," Kompas, 10 Juni 2018, 5.

2 Paul Ricoeur, Hermeneutics and the Human Sciences: Essays on Language, Action and
}

legitimasi kekuasaan sehingga praksis hidup yang baik tidak pernah muncul. Fenomena post-truth berupa berita bohong dan ujaran kebencian sesungguhnya menandai kesadaran yang terpikat pada diri sendiri (tertutup, menolak intersubjektif) yang menyebabkan munculnya cari berpikir egologis. ${ }^{3}$

Di zaman sekarang, kebohongan dan kebenaran nyaris sulit dibedakan. Di era digital yang serba terbuka saat ini, sebuah informasi diterima begitu saja tanpa reserve (syarat), selain cukup punya gawai. Punya gawai tidak pernah mengandaikan berpikir, modalnya cukup jempol, begitulah sering dikatakan. ${ }^{4}$ Sudah berulang kali dikampanyekan "berpikir sebelum berbagi" (think before sharing), klarifikasi, bertabayun, tetapi sebatas di bibir. Inilah yang mengkhawatirkan karena kita semakin jauh dari kebenaran. Andrew Keen mengingatkan bahwa internet tidak hanya mendemokratisasi informasi di luar imajinasi manusia yang paling liar, tetapi juga menggantikan ilmu pengetahuan (knowledge) dengan kebijakan kerumunan (the wisdom of

Interpretation, ed. John B. Thompson (Cambridge: Cambridge University Press, 1982), 99.

${ }^{3}$ Ricoeur, Hermeneutics and the Human Sciences, 20.

${ }^{4}$ Jane Suiter, "Post-truth Politics," Political Insight (December 2016): 25-27. Syailendra Persada dan Istman Musaharun, "Modal Jempol dan Akun Anonim," Tempo, 2-8 Januari 2017, 38-39. 
crowd) yang mengaburkan garis antara fakta dan opini. ${ }^{5}$ Karena yang disasar adalah orang percaya pada opini.

Dalam internet, algoritma menggiring orang-orang yang sepandangan terperangkap dalam ruang yang sama, antar lain ruang mempercayai kabar bohong. Inilah gelembung informasi sebagai efek “gelembung filter" (filter bubble), ${ }^{6}$ yang membuat pesan-pesan manipulatif yang dilontarkan akan semakin mengurung publik yang berpikiran sama. Fenomena ini disebut juga sebagai "algoritma mobokrasi" (mobocratic algorithms). Inilah algoritma yang memberi kekuasaan pada mob atau "kerumunan". 7 Tak mengherankan, efek filter bubble itu semakin menggiring orang menggunakan kacamata kuda. Banyak orang percaya begitu saja ketika Ratna Surampaet mengaku dipukuli oleh 2-3 orang di dekat bandara di Bandung pada 21 September 2018 seusai menghadiri konferensi internasional di kota itu. Bahkan, calon presiden Prabowo Subianto juga

\footnotetext{
${ }^{5}$ Andrew Keen, "The Cult of the Amateur," dalam Online Communication and Collaboration: A Reader, ed. Helen Donelan, Karen Kear dan Magnus Ramage, (London and New York: Routledge, 2010), 251-257.

${ }^{6}$ Keen, "The Cult of the Amateur," 251. M. Subhan SD (2), "Master Manipulator," Kompas, 13 Oktober 2018, 3. Kharisma Dhimas Syuhada, "Etika Media di Era 'Post-Truth'," Jurnal Komunikasi Indonesia V, no. 1, (April 2017): 75-79.

7 Keen, "The Cult of the Amateur," 253. Putut Widjanarko, "Media Sosial yang Beradab," Tempo,
}

percaya. "Apa yang dialami Ibu Ratna ini tindakan yang di luar kepatutan, tindakan jelas melanggar HAM, dan tindakan pengecut karena dilakukan terhadap ibu-ibu yang usianya sudah 70 tahun", kata Prabowo di Jakarta, Selasa malam, 2 Oktober 2018.

Salah satu isu besar pendidikan di Indonesia hari ini adalah rendahnya kemampuan nalar. ${ }^{8}$ Sebuah lembaga riset swasta, Alvara, merilis hasil penelitian tentang peningkatan radikalisme di kalangan terdidik, Juni 2018. ${ }^{9}$ Menurut lembaga ini, kelompok intoleran semakin mendominasi kajian-kajian di tempat kerja, di lembaga dakwah kampus, dan kegiatan keagamaan di sekolah. Ketika pendidikan menjadi tolok ukur untuk menggambarkan realitas sosial pada masa kini dan nanti, indikasi tentang adanya pandangan radikal dalam pembelajaran perlu dicermati secara serius. Sekurang-kurangnya inilah asumsi dasar ketika riset itu mulai dijalankan. Dalam risetnya, Alvara mendapati data

2-8 Januari 2017, 40-41. Wibowo, "Media Sosial dan Mobokrasi,", 2-3.

${ }^{8}$ Kurniawan, "Menjaga Kewarasan dalam Bermedia Sosial Sejak dari Pikiran," 5.

9 Saifur Rohman, "Masa Depan Intoleransi," Kompas, 23 Juni 2018, 7. Lisdawati Wahjudin, "Radicalism Rising among Educated People," International Journal of Multicultural and Multireligious Understanding 6, no. 3, (February 2019): 62-65. 
menarik tentang tingkat popularitas organisasi massa Islam di mata kaum terdidik. Salah satu yang tertinggi adalah Front Pembela Islam (99,1 persen), Lembaga Dakwah Islam Indonesia (63,4 persen), Hizbut Tahrir Indonesia (49,1 persen) dan Front Umat Islam (13,8 persen). Popularitas organisasi ini, di satu sisi memberikan indikasi tentang pemahaman masyarakat terhadap perilaku organisasi tersebut. Di sisi lain popularitas juga memberikan indikasi tentang adanya ideologi dominan dalam wacana keagamaan di tengah-tengah masyarakat sekarang ini. Bila kenyataan itu direfleksikan di dalam dunia pendidikan, ideologi dominan itu nyatanya tidak tertuang di dalam pembelajaran di sekolah maupun perguruan tinggi. ${ }^{10}$ Informasi tentang intoleransi maupun toleransi, misalnya, justru diperoleh melalui "media pembelajaran" di luar praktik belajar-mengajar. Mereka menjadi fundamentalis maupun teroris pun didasarkan pada organisasiorganisasi di luar kurikulum. Sekolah atau perguruan tinggi pada saat yang sama hanya terpaku pada persiapan ujian nasional. Hal itu diperparah oleh sebuah kenyataan, bahwa kebijakan pembelajaran di Indonesia

\footnotetext{
${ }^{10}$ Firly Annisa, "Hijrah Milenial: Antara Kesalehan dan Populisme," Maarif 13, no. 1, (Juni 2018): 3854.

11 Achmad Murtafi Haris, "Mahasiswa Terpapar Radikalisme," Kompas, 11 Juni 2018, 7. Bambang Wiji Asmoro Sadarusalam dan Khoirul Hasan,
}

tidak memberikan ruang untuk aspek kompetensi toleransi bagi peserta didik. Empat kompetensi sebagaimana tercantum dalam PP No. 19 tahun 2005 tentang Standar Nasional Pendidikan, yaitu pedagogik, profesional, kepribadian dan sosial tidak dijadikan sebagai perangkat strategi efektif untuk menjalankan praktik deradikalisasi dan mengembangkan ideologi toleransi.

Bila konteks di atas benar, maka bisa dipahami bahwa Badan Nasional Penanggulangan Terorisme (BNPT) menemukan banyak kampus di Indonesia yang terpapar radikalisme Islam. ${ }^{11}$ Fenomena itu sering diawali dengan banyaknya mahasiswa yang memanjangkan jenggot dan kalangan mahasiswa yang memakai cadar. Selain itu, mereka tidak segan-segan memisahkan tempat duduk antara laki-laki dan perempuan, yang sebelumnya tidak dianggap sebagai masalah. Merebaknya paham itu kebanyakan di fakultas eksakta, baik sains maupun terapan, bukan sosial, humaniora dan agama. Tentang kecenderungan jurusan eksakta terpapar radikalisme agama, di antaranya karena mereka memang pada posisi awam terhadap ilmu

\footnotetext{
"Kontra Propaganda Badan Nasional Penanggulangan Terorisme dalam Menanggulangi Perkembangan Radikalisme di Indonesia," The Indonesian Journal of Politics and Policy 1, no. 1, (Januari 2019): 74-82.
} 
agama sehingga bisa dimasuki pandangan agama apa pun, termasuk yang radikal.

Karena kesadaran merupakan hasil dari muslihat dan penipuan yang bersifat sosial dan personal sekaligus, maka fenomena post-truth tersebut harus dipahami secara hermeneutis. Di sinilah pisau analisis hermeneutik dapat dipakai untuk membedah fenomena post-truth. Diperlukan pisau hermeneutik kritis yang garang terhadapnya, yang maksudnya untuk menguak dimensi pembebasan dari dampak buruk politik post-truth berupa sikap saling curiga, kebencian, segregasi masyarakat hingga lunturnya negara-bangsa dan tumbangnya pemerintahan yang sah. Dalam perspektif pendidikan, hermeneutik kritis bermaksud mengawal tetap terpeliharanya obor kesadaran dalam kehidupan masyarakat yang dasarnya adalah politik pengakuan (politics of recognition) berupa multikulturalisme, toleransi, solidaritas dan keadilan bagi semua. ${ }^{12}$ Tesis tulisan ini bahwa pendidikan sejatinya adalah praksis pembebasan untuk mempertahankan keluhuran budi pekerti manusia sebagai makhluk mulia dan beradab, yaitu kesatuan kata dan tindakan yang dihidupi.

\footnotetext{
${ }^{12}$ David M. Kaplan, Ricoeur's Critical Theory (New York: State University of New York Press, 2003), Bab 6.
}

\section{METODE PENELITIAN}

Pisau bedah yang dipergunakan untuk menganalisis fenomena post-truth tersebut adalah hermeneutic kecurigaan. Paul Ricoeur mengusung "hermeneutik kecurigaan" (hermeneutics of suspicion) sebagai metode yang bertujuan melakukan demistifikasi atas subjek yang pongah, yang dihidupi oleh ketidakpercayaan dan skeptisisme serta melahirkan post-truth. Metode hermeneutik kecurigaan ini mengambil inspirasi dari para guru kecurigaan: Marx, Nietzsche dan Freud, ${ }^{13}$ yang menentang kesadaran dan apa yang dianggap benar dan nyata. Karena apa yang benar sudah dimanipulasi dalam jahitan kebohongan. Bahkan para guru tersebut menempatkan kesadaran palsu dalam kritik bertubi-tubi untuk meruntuhkan ilusi subjek dan menggantikan dengan kesadaran tidak langsung. Kesadaran tidak langsung adalah kesadaran yang dibangun dalam perjumpaan dengan yang lain, sebaliknya kesadaran langsung adalah kesadaran ego yang merasa cukup dengan dirinya dan tidak merasa perlu yang lain. Yang pertama adalah kesadaran karena menerima mediasi. Yang terakhir adalah kesadaran yang menolak mediasi. Yang pertama, kesadaran diterjemahkan sebagai

\footnotetext{
${ }^{13}$ Ricoeur, Hermeneutics and the Human Sciences, 21.
} 
kata-kata yang harus dicek kebenarannya dengan menerima masukan orang lain. Yang terakhir, kesadaran ada karena merasa paling benar. Pada yang terakhir inilah pintu terbuka bagi terciptanya post-truth dalam model-model kebohongan dan ujaran kebencian.

Dalam metodenya, Ricoeur juga menggemakan mediasinya perihal perdebatan Habermas (sisi kritis) dan Gadamer (sisi afirmatif) yang mengerucut pada kearifan praktis (practical wisdom). ${ }^{14}$ Hermeneutik, baik yang garang dan kritis ala hermeneutik Habermas, maupun yang romantik dan afirmatif ala Gadamer, keduaduanya harus tiba pada menafsir diri menuju kearifan praktis. Antara kontem-plasi dan praksis tidak ada dikotomi. Bahkan di antara keduanya, praksis adalah penentu akhir seseorang itu digambarkan seperti apa. Hasilnya sebuah hermeneutik diri yang baru dan terbuka ke ruang publik, secara metodik bergerak dengan pisau kecurigaan terlebih dahulu untuk membuka selubung kepentingan yang bermain di dalam relasi kekuasaan ekonomi-politik yang dominatif, menindas, sarat kebohong-an dan tidak benar terhadap kaum lemah dan miskin

\footnotetext{
${ }^{14}$ Ricoeur, Lectures on Ideology and Utopia, 314. Ricoeur, Oneself as Another, 290.

${ }^{15}$ A. Flood, "'Post-truth' named word of the year by Oxford Dictionaries," diakses 4 Juli 2019, https://www.theguardian.com/books/2016/nov/15/.
}

(langkah pertama), baru dari situ bergerak mengafirmasi sebuah pengharap-an dalam tindakan konkret hidup baik dan bicara benar bersama orang lain (langkah kedua).

Pembahasan dalam artikel ini akan meliputi tiga langkah. Langkah pertama adalah mendeskripsikan post-truth itu sendiri untuk mendapatkan duduk permasalahan secara jelas. Langkah kedua adalah memaparkan usaha-usaha mengembalikan kesadaran dalam wilayah tindakan dengan memanfaatkan hermeneutik kecurigaan. Dan akhirnya dipaparkan sebuah konstruksi pendidikan Kristiani di era post-truth.

\section{HASIL DAN PEMBAHASAN}

\section{"Post-Truth" A Word of the Year 2016}

Oxford English Dictionary menobatkan istilah "post-truth" sebagai "Word of the Year 2016."15 Tahun 2017 juga dinobatkan sebagai annus horribillis, yaitu tahun yang mengerikan dalam hal penyebaran kabar bohong dan sesat. Posttruth atau pasca-kebenaran didefinisikan sebagai "keadaan di mana fakta-fakta obyektif kurang berpengaruh dalam membentuk opini publik daripada menarik emosi dan kepercayaan pribadi."16 Salah satu

\footnotetext{
16 Francesco Occhetta, "A Time of Post-Truth or Post-Consciousness?" La Civilta Cattolica 1, (15 July 2017): 14-23. Stewart Lockie, "Post-truth politics and the social sciences," Environmental Sociology 3, no. 1, (2017): 1-5. Susana Salgado, "Online Media Impact on Politics. Views on Post-
} 
contoh yang sering dijadikan referensi posttruth adalah pemilihan presiden Amerika Serikat 2016. Donald Trump terpilih menjadi presiden diduga karena kampanye hoax di medsos yang dilancarkan oleh Rusia, salah satunya dengan mencari keburukan lawan politik, fitnah, hingga pembunuhan karakter, Hillary Clinton. ${ }^{17}$ Hampir berbarengan dengan populernya kosa kata posttruth adalah munculnya istilah pro-paganda Rusia firehose of falsehood (FoF) menyusul kampanye Presiden Rusia Vladimir Putin ketika melakukan aneksasi Semenanjung Krimea menjadi wilayah Rusia pada 2014. ${ }^{18}$ Metode propaganda FoF atau semburan dusta ini, yang diberi lahan subur oleh post-truth, diyakini berhasil di Inggris pada kasus Brexit (Britanian Exit) dan Pilpres AS tahun 2016, serta terpilihnya Bolsonaro sebagai Presiden Brasil pada 2018.

Yang eksistensial dari post-truth adalah ketakutan. ${ }^{19}$ Lagi-lagi Presiden

truth Politics and Post- postmodernism," International Journal of Media \& Cultural Politics 14, no. 3, (2018): 317-331.

${ }^{17}$ Meredith A. Levine, "Journalism Ethics and the Goldwater Rule in a 'Post-Truth' Media World," The Journal of the American Academy of Psychiatry and the Law 45, no. 2, (2017): 241-248. A. SetyoWibowo, "Media Sosial dan Mobokrasi," Basis 11-12, Tahun ke-66, (2017): 2-3.

18 Norman Vasu, Benjamin Ang, Terri-Anne-Teo, Shashi Jayakumar, Muhammad Faizal, dan Juhi Ahuja, Fake News: National Security in the PostTruth Era, Policy Report January (Singapore: S. Rajaratnam School of International Studies and Nanyang Technological University, 2018), 18.
Donald Trump, tokoh populis nomor satu, menurut Vlad Petre Glăveanu, jelas menggunakan ketakutan sebagai alat politiknya. Trump pernah mengatakan, "Kekuasaan yang sesungguhnya - sebenarnya saya tak ingin menggunakan kata ini — adalah ketakutan."20 Sejak 2016 hingga 2019, ketakutan paling laku dijual di pasar. Di pasar politik, konkretnya, ketakutan bisa diancamkan pada massa untuk membuat mereka panik. Namun, massa tidak hanya jadi objek, malah bisa menjadi subjek atau sumber ketakutan. Caranya gampang, cukup dengan menyulut api kemarahan mereka. Sementara siapa yang menyulut korek api tak diketahui lagi. Provokasi biasanya dikerjakan oleh tangan-tangan tersembunyi. Secara kolektif terjadilah intellectual dislocation, yaitu ketidakmampuan memahami apa yang terjadi dan siapa aktornya. ${ }^{21}$ Dalam keriuhan ini berlaku mekanisme kambing hitam, di mana agresi ketakutan dilampiaskan pada

Irwan Julianto, "Epidemi 'Post-Truth'," Kompas, 23 April 2019, 7.

19 Vlad Petre Glăveanu, "Psychology in the PostTruth Era," Europe's Journal of Psychology 13, no. 3, (2017): 375-377.

20 Glăveanu, "Psychology in the Post-Truth Era," 375-377. Munich Security Report, "Post-Truth, Post-West, Post-Order?" (2017): 1-89. Sindhunata, "Memedi Sawah," Kompas, 23 Februari 2019, 6.

21 Joshua Forstenzer, "Something Has Cracked: Post-Truth Politics and Richard Rorty's Postmodernist Bourgeois Liberalism," Ash Center Occasional Papers (July 2018): 1-40. Komaruddin Hidayat (2) “Konspirasi," Kompas, 18 Januari 2019, 6. 
"tumbal" kemarahan, pengejaran dan pembunuhan. $^{22}$ Di sini massa sejatinya mewakili kelemahan bukan kekuatan. Ketakutan pun menjadi eksistensial.

Post-truth adalah era ketika informasi laksana sebuah pendulum yang bergerak dari satu sisi ke sisi yang lain tanpa mengharapkan kesadaran. Pada era posttruth, orang tidak mencari kebenaran yang berdasarkan fakta, tetapi mencari afirmasi, konfirmasi dan dukungan terhadap keyakinan yang mereka miliki. Post-truth tumbuh karena tindakan-tindakan berikut ini: ujaran kebencian, suara-suara mencemooh lembaga resmi dan layanan publik, mempermainkan tingkat emosi dan keyakinan tidak rasional dalam masyarakat, menyebarkan kecurigaan, dan menyebarkan berita bohong. Post-truth biasanya bergandengan dengan kemunculan teori konspirasi yang mirip hoax, lebih mendalam dan bertahan lama. $^{23}$ Keadaan lain yang sangat menyuburkan munculnya post-truth adalah jaringan sosial (dark social) yang bergerak jauh meninggalkan fakta, digantikan dengan emosi dan keyakinan yang mudah

22 Sindhunata, Kambing Hitam: Teori Rene Girard (Jakarta: Gramedia, 2007).

${ }^{23}$ Tuukka Ylä-Anttila, "Populist Knowledge: 'Posttruth' Repertoires of Contesting Epistemic Authorities," European Journal of Cultural and Political Sociology (2018): 1-30. Hidayat (2), "Konspirasi," 6.

24 Jayson Harsin, "Post-Truth and Critical Communication," Oxford Research Encyclopedia of dipermainkan. Ditunjang pula oleh politik populisme,${ }^{24}$ yang maksudnya memompa ketidakpuasan terhadap institusi politik dan ekonomi.

Menurut Jane Suiter, orang yang sering disebut sebagai salah satu tokoh besar post-truth adalah Joseph Goebbels (1897-1945). Goebbels adalah tokoh penting partai Nazi, yang pernah mengatakan, "Siapa yang bicara pertama kali, dialah yang benar."25 Dalam sejarah tercatat, Goebbels adalah pendesain kebohongan nomor satu di dunia. Ia seorang propagandis yang mengawal sepak terjang Hitler dengan Nazi-nya semasa Perang Dunia II pada dekade 1940-an. Goebbels mendesain propaganda menyebar kebohongan untuk membentuk opini publik dan menguasai massa. Ia mewanti-wanti, kebohongan harus diulangi terus-menerus, lama-lama dipercaya sebagai "kebenaran.” Itulah posttruth. Sang boss, Adolf Hitler, gemar menggunakan ketakutan untuk memupuk kekuasaan politiknya. ${ }^{26}$ Ironisnya, Hitler seakan beroleh pembenaran politiknya pada pemikiran filsuf ternama Martin Heidegger.

Communication (21 December 2018): 1-36. YläAnttila, "Populist Knowledge," 25. Yuna Farhan, "Politik Populisme Anggaran," Kompas, 23 Maret 2019, 6 .

${ }^{25}$ Jane Suiter, "Post-truth Politics," Political Insight (December 2016): 25-27. M. Subhan SD (1), "Likuefaksi Politik," Kompas, 6 Oktober 2018, 4.

${ }^{26}$ Glăveanu, "Psychology in the Post-Truth Era," 375-377. Sindhunata, "Memedi Sawah," 6. 
Bak gayung bersambut Heidegger pun bergabung dengan partai Nazi. Heidegger yang di mata para muridnya - seperti E. Levinas - sering bersabda tentang menjadi manusia otentik di tengah abad kematian melanda manusia, ${ }^{27}$ justru di mata Hitler membenarkan keberadaan manusia menuju kematian dan ketiadaan (Sein-zum-Tode). Yang eksistensial dari kematian (Tode) dan ketiadaan (Nichts, Nothing) adalah ketakutan (Angst). Karena eksistensial, ketakutan bisa dimanfaatkan untuk apa saja, termasuk beroleh kekuasaan. Peluang memperoleh kekuasaan inilah yang dipakai Hitler untuk mengesahkan rezimnya yang fasis dan otoriter itu sebagai rezim penebar ketakutan dan kebohongan. Perilaku Hitler ini dapat digolongkan sebagai post-truth.

Manusia tidak kedap terhadap kebenaran, tetapi ia bisa mengabaikannya. Istilah post-truth melukiskan sebuah kondisi ketika kebenaran dianggap tak lagi penting dalam ranah publik, tetapi hal itu sama sekali tidak berarti bahwa kebenaran tidak penting. Mengapa orang bisa tidak tertarik pada kebenaran? Karena manusia tidaklah serasional seperti yang disangka. Nalar kita tidak netral, tetapi tendensius dan

\footnotetext{
${ }^{27}$ R. Bernasconi dan Tina Chanter, "The Face of the Other: A Review of the Work of Emmanuel Levinas," Religious Studies Review 16, no. 3, (July 1990): 227-228. K. Bertens, Filsafat Barat Abad XX: Jerman-Inggris, (Jakarta: Gramedia, 1990), 143.
}

sarat kepentingan apalagi jika hal itu menyangkut politik. Lee McIntyre dalam PostTruth menyebutnya "motivated reasoning,"28 yaitu nalar yang cepat mengubah selentingan tentang politikus sontoloyo, tampang Boyolali dan sejenisnya menjadi kontroversi dangkal yang menyeret publik ke dalam rivalitas "kita versus mereka," yakni pihak sendiri selalu benar, sedangkan pihak lawan pasti salah.

Dalam konteks pendidikan, posttruth adalah ketidakbenaran yang tidak mengandung tiga aspek, yakni fakta, moral publik dan ketulusan..$^{29}$ Pertama, post-truth meremehkan perbedaan antara opini dan berita, fakta dan hoaks, fiksi dan realitas, dan memilih menyebar data palsu sehingga publik kebingungan dan mencari pegangan pada kebohongan. Kedua, hilangnya moral publik, yang berarti perilaku publik dikendalikan oleh kebencian dan intoleransi. Ketiga, melawan ketulusan, sebagai komunikasi yang dasarnya saling curiga dan retorika narsistik yang membelah antara kawan dan lawan. Hal ini meningkatkan iklim ketidakpercayaan timbal balik dan potensi terjadinya kekerasan antar individu hingga kolektif.

${ }^{28}$ Lee McIntyre, Post-Truth (Cambridge, MA: MIT Press, 2018), 42. F. Budi Hardiman, "Pentingnya Kebenaran,” Kompas, 30 Nopember 2018, 6.

${ }^{29}$ McIntyre, Post-Truth, 35. Hardiman, "Pentingnya Kebenaran," 6. 


\section{Kembalinya Kesadaran}

Post-truth sebagai salah satu unsur bawaan dalam globalisasi imperialistik telah membutakan mata batin manusia akan kesadaran. Di era ini yang muncul dan berkembang adalah kesesatan berpikir. ${ }^{30}$ Karena itu diperlukan upaya kritis untuk membawa kembali kesadaran ke dalam wilayah praksis tindakan manusia. Mengapa? Karena post-truth paling jelas menyasar wilayah tindakan manusia. Salah satu upaya ini dapat dihasilkan dari sebuah perenungan hermeneutis. Sekaligus perenungan ini bertujuan mengonstruksi sebuah praksis pendidikan Kristiani yang berbasis pada kesadaran dan diterjemahkan dalam praksis.

Menurut Paul Ricoeur, dalam diskursus teori-teori hermeneutik, terdapat dua sayap hermeneutik yang penting dalam rangka menganalisis konteks. ${ }^{31}$ Pertama, gestur hermeneutik afirmatif yang rendah hati, bahkan cenderung nrimo, atas pelbagai kondisi historis yang membuat seluruh pemahaman manusia mesti mengakui keterbatasannya. Kedua, gestur hermeneutik kritis yang gagah berani, bahkan cenderung pongah, yang diarahkan untuk menampik distorsi komunikasi manusia. Terhadap

30 Alexandra Juhasz, "Radical Digital Media Literacy in a Post-Truth Anti-Trump Era," A Socialist, Feminist, and Anti-Racist Journal on the Theory and Practice of Teaching, no. 111, (Summer 2018): 23-29. yang pertama, yaitu hermeneutik, Ricoeur mengatakan bahwa dirinya juga bagian dari proses historis itu, dan terhadap yang kedua yang disebut juga kritik ideologi, Ricoeur menentang komunikasi manusia yang dipalsukan, yang dibimbing oleh sebuah konsep komunikasi bebas tak terbatas. Khusus komunikasi yang palsu, kritik ditujukan agar wilayah tindakan tidak kehilangan panggilan etisnya, yaitu hidup baik bersama yang lain.

Filsafat Ricoeur dapat dikategorikan sebagai filsafat kesadaran (consciousness). ${ }^{32}$ Sekalipun kesadaran menjadi basis hermeneutik filsafatnya, namun kesadaran itu sendiri adalah tugas yang tidak pernah selesai. Mengapa? Menurut Ricoeur kesadaran tidak pernah bersifat langsung (immediate), tetapi dimediasi. Dengan cara demikian, Ricoeur mengambil tikungan penting dalam filsafatnya meninggalkan proyek kesadaran Cartesian yang solipsistis dan egologis. Mengapa? Karena bagi Descartes kesadaran itu murni tanpa relasi. Aku tidak membutuhkan teman sandingan. Ada pun teman itu hanya ada dalam relasi yang saling curiga dan mewujud dalam konflik dan peperangan. Tikungan yang

${ }^{31}$ Ricoeur, Hermeneutics and the Human Sciences, 87-88.

${ }^{32}$ Ricoeur, The Conflict of Interpretations, 119-120, 260, 324. Ricoeur, Oneself as Another, 186. 
dibuat Ricoeur adalah usaha memberi tempat pada "yang lain" (the other). Di sini kedudukan yang lain menjadi penting. Bahwa kesadaran diri dimediasi oleh kehadiran yang lain. Yang lain atau alteritas dipahami karena di dalam kategori subjek masih memungkinkan penampakan "yang lain.” Jadi, "yang lain” bukan menampakkan diri, tetapi subjek sadar akan "yang lain.” Subjek yang mencapai kesadaran adalah subjek yang terbuka dan menerima pluralitas "yang lain" berkat kewajibannya untuk mengambil jarak terhadap diri. Kritik atas ego adalah kesempatan untuk merayakan kehadiran liyan.

Menurut Kevin Vanhoozer, hermeneutik Paul Ricoeur dapat pula dikategorikan sebagai filsafat antropologi. ${ }^{33}$ Pemikiran Ricoeur juga disebut sebagai teologi, yaitu teologi tentang manusia (theo-anthropology). ${ }^{34}$ Sebagai filsafat atau teologi tentang manusia, maka pemikiran Ricoeur bersentuhan langsung dengan urusan-urusan publik. Diskursus ruang publik Ricoeur pertama-tama terkait de-

${ }^{33}$ Kevin J. Vanhoozer, Biblical Narrative in the Philosophy of Paul Ricoeur: A Study in Hermeneutics and Theology (Cambridge: Cambridge University Press, 1990), 119.

${ }^{34}$ Boyd Blundell, Paul Ricoeur between Theology and Philosophy: Detour and Return (Bloomington and Indianapolis: Indiana University Press, 2010), 150-169. John van den Hengel, "Paul Ricoeur's Oneself as Another and Practical Theology," Theological Studies 55, no. 3, (September 1994): ngan subjek yang mencapai kesadaran karena terbuka dan menerima pluralitas "yang lain" serta berkat kewajibannya untuk mengambil jarak terhadap diri. Filsafat atau teologi antropologi menurut Ricoeur berarti tugas publik dari subjek yang telah mengalami kesadaran untuk terbuka keluar mengemansipasi atau membebaskan ruang publiknya yang penuh dengan penindasan dan ketidakadilan. ${ }^{35}$ Bagi Ricoeur, subjek tidak terpisah dari yang lain. Subjek terbuka pada urusanurusan publik, untuk mewujudkan "aiming at the good life with and for others in just institutions". ${ }^{36}$ Subjek yang sadar pada urusan-urusan publik ini membutuhkan topangan hermeneutik yang maksudnya sebagai sarana menafsir diri untuk teguh pada panggilan etis emansipatoris.

Dari kedua sayap hermeneutik itu, Ricoeur dalam Hermeneutics and the Human Sciences mengatakan bahwa watak dasar hermeneutik pertama-tama adalah kritis. ${ }^{37}$ Dalam menafsir realitas, sikap dasar yang terbentuk adalah kecurigaan

458-480. F. Budi Hardiman, Seni Memahami: Hermeneutik dari Schleiermacher sampai Derrida (Yogyakarta: Kanisius, 2015), 257.

${ }_{35}$ Paul Ricoeur, Memory, History, and Forgetting, trans Kathleen Blamey dan David Pellauer (Chicago \& London: The University of Chicago Press, 2004), 491-493.

${ }^{36}$ Ricoeur, Oneself as Another, 172, 180.

${ }^{37}$ Ricoeur, Hermeneutics and the Human Sciences, 63. 
(suspicion) sebagai sikap menunda pemahaman dengan jalan memutar (long detour) menerima mediasi dari yang lain. Subjek menunda pemahaman dengan menciptakan ruang bagi liyan. Aku tidak buru-buru tiba pada kesadaran dengan cara menolak jalan pendek (short route) dan diganti menempuh jalan panjang (long route) berupa melihat, berjumpa, mendengar, membaca dan berbicara dengan yang lain yang tersimpan dalam teks, simbol dan termasuk kehadiran orang lain.

Dalam konteks post-truth, maka jalan kritis ini ditujukan pada ideologi yang mengontrol pembaca bahkan komunitas, untuk menyadari apa saja yang terjadi dan menyumbang pemaknaan sebuah realitas yang tidak jarang berkaitan erat dengan kepentingan tertentu ${ }^{38}$ Setelah menyadarinya kita dapat menentukan strategi apa yang jauh lebih berbicara secara pragmatis bagi kepentingan etis yang liberatif.

Bagaimana kesadaran dapat kembali? Ricoeur mengatakan antara lain dengan membaca. Membaca memperkenalkan saya kepada ragam ego imajinatif (reading introduces me to imaginative variations of the ego), ${ }^{39}$ yaitu melalui proses berjumpa dan berdialog dengan pemikiran-pemikiran

\footnotetext{
${ }^{38}$ Ricoeur, Hermeneutics and the Human Sciences, 87-100.

${ }^{39}$ Ricoeur, Hermeneutics and the Human Sciences, 94.
}

lain dari apa yang dibaca. Karena kebenaran menurut Ricoeur bersifat relasional, maka aku tidak membangun kebenaran sendiri (baik menurut diri sendiri maupun kelompok sendiri) apalagi kebenaran itu bersifat ilusi alias post-truth. Dengan berdialog dengan pemikiran lain yang ada di dalam teks dan simbol, aku terbuka pada kerendahan hati menerima mediasi yang lain. Bahwa aku hanya satu dari sekian akuaku yang lain. Bahkan ego dibenturkan dengan ego-ego yang lain melalui penerimaan interupsi dan kritik yang datangnya dari yang lain. Kesadaran pada "ragam ego imajinatif" ini-lah yang menurut Ricoeur pembuka kemungkinan bagi kritik atas ilusi subjek yang egologis (berpusat pada diri sendiri) dalam praktik post-truth. Setelah itu, imajinasi atas ego yang jamak itu dikonkretkan dalam perjumpaan otentik sehingga terbetuk praksis tindakan sebagai wujud dari kesadaran yang sudah terbentuk itu.

Pendidikan di Era Post-Truth: Kesatuan Kata dan Tindakan

Saiful Rohman mengidentifikasi tiga persoalan pendidikan dalam konteks intoleransi. ${ }^{40}$ Pertama, desain pembelajaran

\footnotetext{
${ }^{40}$ Rohman, "Masa Depan Intoleransi," 7. Wahjudin, "Radicalism Rising among Educated People," 65.
} 
yang mengarusutamakan toleransi belum mendapatkan tempat dalam kesadaran pendidikan maupun pemegang kebijakan. Sebuah ideologi toleransi tidak bisa muncul begitu saja tanpa proses pembelajaran yang memadai. Kompetensi pertama (spiritual) dan kompetensi kedua (sosial) diarahkan pada sikap baik secara normatif tanpa adanya pembelajaran ideologis yang berpihak pada nilai-nilai Pancasila. Kita boleh berharap banyak pada rencana pemerintah untuk pendidikan 2020 yang berfokus pada pendidikan karakter yang di dalamnya mengandung nilai toleransi, integritas, mandiri, kolaborasi dan nasional. ${ }^{41}$ Lima nilai ini diharap dapat membentuk individu yang kritis, empatis dan merdeka dari jebakan intoleransi. Kedua, di dalam kurikulum sendiri tidak ada pendekatan deradikalisasi untuk setiap mata pembelajaran. Dalam kurikulum nasional hasil revisi Kurikulum 2013, ditunjukkan tentang pendekatan saintifik yang mesti digunakan dalam praktik pembelajaran. Ironisnya metode itu berlaku untuk setiap mata pelajaran. Dimulai dari mengamati, menanya, mengumpulkan informasi, mengasosiasi dan mengomunikasikan. Yang berbeda bahwa

\footnotetext{
41 DNE, "Pendidikan Karakter Jadi Payung," Kompas, 10 Mei 2019, 9.

42 DNE, "Pendidikan Karakter Jadi Payung," 9. Sidharta Susila, "Melumpuhkan Pendidikan dengan Hoaks," Kompas, 2 Mei 2019, 6.
}

rencana pendidikan 2020 adalah pada penguatan kemampuan literasi dan persepsi, baik guru dan murid, terhadap hoaks yang berbahaya bagi nilai nasionalisme, toleransi dan kemandirian dengan pendekatan berbasis masalah. ${ }^{42}$ Ketiga, pemikiran global yang berideologi liberal dan pragmatis memiliki kemampuan yang sangat kuat untuk memengaruhi para pemegang kebijakan di bidang pendidikan. Pemerintah meyakini bahwa empat kompetensi abad 21 sebagaimana dirumuskan oleh Dennis van Roekel sebagai 4 C, ${ }^{43}$ yaitu critical thinking, communication, collaboration dan creativity, yang menitikberatkan pada bertanya sebagai wujud berpikir kritis dan kreativitas, perlu diimbangi dengan pendidikan yang berpijak pada ideologi kebangsaan. Slogan pendidikan berkarakter tidak cukup. Kita perlu menambah strategi pembelajaran yang berbasis pada penanaman ideologi yang toleran, keragaman dan multikultural. Semua hal tersebut adalah usaha menangkal bahaya post-truth.

Strategi pembelajaran di atas sekali lagi adalah bagian dari upaya memulihkan kesadaran. Banyak pakar pendidikan telah menganalisis mengapa nilai-nilai toleransi

\footnotetext{
${ }^{43}$ Dennis van Roekel, "Global Competence Is a $21 \mathrm{st}$ Century Imperative," NEA Education Policy and Practice Department (2010): 1-4. Kai Horsthemke, "“\#FactsMustFall'? - Education in a Post-truth, Post-truthful World," Ethics and Education (28 June 2017): 1-16.
} 
dan multikulturalisme sekarang bagaikan api di dalam sekam yang mudah terbakar atau dibakar dan meninggalkan sisa berupa intoleransi dan perpecahan masyarakat. Salah satu jawabnya adalah makin menurunnya budaya literasi atau budaya baca. ${ }^{44}$ Dalam perspektif hermeneutik Ricoeur, literasi tidak sekadar membaca, tetapi membaca untuk memahami secara kritis. Dalam diskursus hermeneutik sudah jamak diketahui bahwa "membaca" menekankan pada pembaca teks yang mempunyai perspektif atau pendekatan tertentu terhadap teks. Sementara "memahami” (dekat dengan "menafsir") menekankan pada kemampuan menggali teks dan makna yang terdapat di dalam atau di belakang teks. ${ }^{45}$ Kegiatan membaca sebagai memahami membawa seseorang pada kedalaman informasi, keutuhan informasi, serta pemikiran kritis yang menyertai terbitnya kesadaran. Ricoeur menamai proses ini sebagai refleksi. ${ }^{46}$ Refleksi akan mudah dihasilkan dari mereka yang memiliki kebiasaan

44 Song-Chong Lee, "Boundary-Breaking Disposition against Post-Truth: Five Big Questions for Religious Education," Religions 9, no. 316, (2018): 1-8. Thomas Honeck, "A Touch of Posttruth: the Roles of Narratives in Urban Policy Mobilities," Geographica Helvetica 73, (2018): 133-145. Ignatius Haryanto, "Imbangi Hoaks dengan Tradisi Baca," Kompas, 14 September 2017, 7.

${ }^{45}$ Ricoeur, Hermeneutics and the Human Sciences, 43. Richard E. Palmer, Hermeneutics: Interpretation Theory in Schleirmacher, Dilthey, Heidegger, and membaca buku. Kelambatan dalam mencerna informasi bagaikan "jalan panjang" (long detour) mediasi dan menjadi senjata ampuh meruntuhkan post-truth.

Pemahaman melalui kebiasaan membaca adalah jalan panjang (long route) dan tidak pernah bersifat langsung (immediate). ${ }^{47}$ Berbagai simbol, bahasa, hingga perjumpaan otentik dengan liyan menjadi jalan melahirkan pemahaman. Dengan membaca untuk memahami maka kita dapat keluar dari kesadaran palsu yang diciptakan oleh post-truth. Sehingga praksis pendidikan melalui budaya membaca adalah proyek kesadaran tentang diri yang kritis pada ilusi subjek dalam rupa ketertutupan, kebohongan dan ujaran kebencian. Tujuan dari proyek kesadaran ini adalah agar pendidikan tidak hanya soal menambah kognisi melalui kecakapan berolah pikir dan berolah kata saja. Kata-kata tidak cukup untuk menandai kesadaran. Karena, menurut Ricoeur, yang paling penting katakata diterjemahkan dalam tindakan. ${ }^{48}$

Gadamer (Evanston: Northwestern University Press, 1980), 12, 14-32.

${ }^{46}$ Ricoeur, Hermeneutics and the Human Sciences, 18.

${ }^{47}$ Ricoeur, Hermeneutics and the Human Sciences, 264. Randolf C. Flores, "Wrestling with the Text Paul Ricoeur's Hermeneutics and the HistoricalCritical Method in Biblical Exegesis," Diwa XXVII, no. 2, (November 2002), 136.

${ }^{48}$ Ricoeur, Hermeneutics and the Human Sciences, 8-9, 16-17. 
Dengan tindakan setiap kata dan kalimat dibuktikan tidak pernah ingkar janji atau berbohong. Dalam konteks pendidikan, Joseph Ernest Mambu merumuskannya sebagai "pendidikan yang memerdekakan," yang melalui service-learning (melayani dan belajar), ${ }^{49}$ pendidik dan pemelajar menangkap cerita-cerita dari masyarakat berkaitan dengan ketidakadilan, kerusakan lingkungan, dan isu lainnya, untuk melahirkan tindakan transformasi sosial. Proyek kesadaran pendidikan adalah ketika kata menyatu dengan tindakan. Dengan tindakan, hasil pendidikan adalah penciptaan insan yang utuh berkarakter dan bermoral, toleran, bertanggung jawab pada diri, hidup orang lain dan demi keutuhan ciptaan.

Terhadap makin maraknya posttruth, di Indonesia, muncul berbagai gerakan, misalnya edukasi dan peningkatan literasi media -salah satunya $21^{\text {st }}$ century skill, dari berbagai kelompok anti-hoax, yang digagas oleh siapa saja termasuk oleh komunitas agama. ${ }^{50}$ Persekutuan Gerejagereja di Indonesia (PGI), misalnya, pada

49 Joseph Ernest Mambu, "Pendidikan yang Memerdekakan," Kompas, 7 Mei 2019, 6.

${ }^{50}$ Roekel, "Global Competence Is a 21 st Century Imperative," $3 . \quad$ Kai Horsthemke, "“\#FactsMustFall'? - Education in a Post-truth, Post-truthful World," Ethics and Education (28 June 2017): 1-16. Widjanarko, "Media Sosial yang Beradab," 40. Adrianus Riswanto, "Allah di Tengah Hoax," Rohani 03, Th. ke-64, (Maret 2017): 38-40.
2018 mengeluarkan buku Warga Gereja Merespon Revolusi Media Sosial: Panduan Bermedia Sosial. ${ }^{51}$ Tujuan utama penerbitan ini adalah memberi pendidikan medsos kepada anak-anak sejak dini. Sehingga mereka menjadi pengguna medsos yang sadar, bertanggung jawab dan tidak kehilangan daya kritis pada kontenkonten negatif dan radikal yang berdampak kepada diri mereka sendiri dan orang lain. Opini yang ditulis oleh Muhadjir Effendy pada Hari Pendidikan Nasional 2 Mei 2019 lalu, "Refleksi Hari Pendidikan," menegaskan perlunya kecerdasan literasi yang komprehensif dalam bingkai moralitas bangsa Indonesia yang religius dan demokratis, mengatasi post-truth dan mengembalikan kesadaran di wilayah tindakan.

\section{KESIMPULAN}

Melalui perenungan hermeneutis Ricoeurian, ditemukan bahwa problem pendidikan lintas generasi di Indonesia, pertama-tama bukan soal ditataran praktispolitis, tetapi hal ini terkait dengan hilangnya kesadaran dalam relung-relung hati

Said Aqil Siroj, "Kembali ke Literasi," Kompas, 3 Mei 2019, 7.

51 PGI, Warga Gereja Merespon Revolusi Media Sosial: Panduan Bermedia Sosial (Jakarta: PGI, 2018).

${ }^{52}$ Muhadjir Effendy, "Refleksi Hari Pendidikan," Kompas, 3 Mei 2019, 6. Yudi Latif, "Pendidikan Era Baru," Kompas, 2 Mei 2019, 6. Yanuar Nugroho, "Menyoal Pendidikan di Indonesia," Kompas, 3 Mei 2019, 6. 
nurani yang merembet ke wilayah tindakan di ruang publik. Karena itu, pemulihan subjek hanya mungkin dengan menyatukan kata dan perbuatan. Kata-kata yang baik harus segaris pula dengan tindakan yang baik. Dalam perspektif pendidikan, melalui pembudayaan membaca, maka tindakan yang baik mengandaikan subjek yang terbuka, dialogis dan tidak netral dari panggilan etis. Dalam tindakan setiap individu ditagih janjinya untuk bertanggung jawab atas hidup orang lain dengan tidak menjadi pembohong atau penipu.

\section{DAFTAR PUSTAKA}

Annisa, Firly. "Hijrah Milenial: Antara Kesalehan dan Populism." Maarif 13, no. 1, (Juni 2018): 38-54.

Bernasconi, R., dan Tina Chanter. "The Face of the Other: A Review of the Work of Emmanuel Levinas." Religious Studies Review 16, no. 3, (July 1990): 227-228.

Bertens, K. Filsafat Barat Abad XX: Jerman-Inggris. Jakarta: Gramedia, 1990.

Blundell, Boyd. Paul Ricoeur between Theology and Philosophy: Detour and Return. Bloomington and Indianapolis: Indiana University Press, 2010.

DNE. "Pendidikan Karakter Jadi Payung." Kompas, 10 Mei 2019.

Effendy, Muhadjir. "Refleksi Hari Pendidikan.” Kompas, 3 Mei 2019.

Farhan, Yuna. "Politik Populisme Anggaran." Kompas, 23 Maret 2019.
Flood, A. " "Post-truth' named word of the year by Oxford Dictionaries." Diakses 4 Juli 2019.

https://www.theguardian.com/books/2016/ nov/15/.

Flores, Randolf C. "Wrestling with the Text Paul Ricoeur's Hermeneutics and the Historical-Critical Method in Biblical Exegesis." Diwa XXVII, no. 2, (November 2002).

Forstenzer, Joshua. "Something Has Cracked: Post-Truth Politics and Richard Rorty's Postmodernist Bourgeois Liberalism." Ash Center Occasional Papers (July 2018): 140.

Glăveanu, Vlad Petre. "Psychology in the Post-Truth Era." Europe's Journal of Psychology 13, no. 3, (2017): 375-377.

Hardiman, F. Budi. "Pentingnya Kebenaran.” Kompas, 30 Nopember 2018.

- Seni Memahami: Hermeneutik dari Schleiermacher sampai Derrida. Yogyakarta: Kanisius, 2015.

Haris, Achmad Murtafi. "Mahasiswa Terpapar Radikalisme." Kompas, 11 Juni 2018.

Harsin, Jayson. "Post-Truth and Critical Communication." Oxford Research Encyclopedia of Communication (21 December 2018): 1-36.

Haryanto, Ignatius. "Imbangi Hoaks dengan Tradisi Baca.” Kompas, 14 September 2017.

Hengel, John van den. "Paul Ricoeur's Oneself as Another and Practical Theology." Theological Studies 55, no. 3, (September 1994): 458-480.

Hidayat, Komaruddin. "Konspirasi." Kompas, 18 Januari 2019. 
Honeck, Thomas. "A Touch of Post-truth: the Roles of Narratives in Urban Policy Mobilities." Geographica Helvetica 73, (2018): 133-145.

Horsthemke, Kai. “"\#FactsMustFall'? Education in a Post-truth, Posttruthful World." Ethics and Education (28 June 2017): 1-16.

Juhasz, Alexandra. "Radical Digital Media Literacy in a Post-Truth AntiTrump Era." A Socialist, Feminist, and Anti-Racist Journal on the Theory and Practice of Teaching no. 111, (Summer 2018): 23-29.

Julianto, Irwan. "Epidemi 'Post-Truth'." Kompas, 23 April 2019.

Kaplan, David M. Ricoeur's Critical Theory. New York: State University of New York Press, 2003.

Keen, Andrew. "The Cult of the Amateur." Dalam Online Communication and Collaboration: A Reader, edited by Helen Donelan, Karen Kear dan Magnus Ramage. London and New York: Routledge, 2010.

Kurniawan, Aloysius Budi. "Menjaga Kewarasan dalam Bermedia Sosial Sejak dari Pikiran." Kompas, 10 Juni 2018.

Latif, Yudi. "Pendidikan Era Baru." Kompas, 2 Mei 2019.

Lee, Song-Chong. "Boundary-Breaking Disposition against Post-Truth: Five Big Questions for Religious Education." Religions 9, no. 316, (2018): 1-8.

Levine, Meredith A. "Journalism Ethics and the Goldwater Rule in a 'PostTruth' Media World." The Journal of the American Academy of Psychiatry and the Law 45, no. 2, (2017): 241-248.
Lockie, Stewart. "Post-truth Politics and the Social Sciences." Environmental Sociology 3, no. 1, (2017): 1-5.

Mambu, Joseph Ernest. "Pendidikan yang Memerdekakan." Kompas, 7 Mei 2019.

McIntyre, Lee. Post-Truth. Cambridge, MA: MIT Press, 2018.

Munich Security Report. "Post-Truth, PostWest, Post-Order?” (2017): 1-89.

Nugroho, Yanuar. "Menyoal Pendidikan di Indonesia.” Kompas, 3 Mei 2019.

Occhetta, Francesco. "A Time of PostTruth or Post-Consciousness?" La Civilta Cattolica 1, (15 July 2017): 14-23.

Palmer, Richard E. Hermeneutics: Interpretation Theory in Schleirmacher, Dilthey, Heidegger, and Gadamer. Evanston: Northwestern University Press, 1980.

Persada, Syailendra, dan Istman Musaharun. "Modal Jempol dan Akun Anonim." Tempo, 2-8 Januari 2017.

PGI. Warga Gereja Merespon Revolusi Media Sosial: Panduan Bermedia Sosial. Jakarta: PGI, 2018.

Ricoeur, Paul. Memory, History, and Forgetting. Trans. by Kathleen Blamey and David Pellauer. Chicago \& London: The University of Chicago Press, 2004.

. Oneself as Another. Trans. by Kathleen Blamey. Chicago and London: The University of Chicago Press, 1992.

. Lectures on Ideology and Utopia. Edited by George H. Taylor. New York: Columbia University Press, 1986. 
. Hermeneutics and the Human Sciences: Essays on Language, Action and Interpretation. Edited by John B. Thompson. Cambridge: Cambridge University Press, 1982.

Riswanto, Adrianus. "Allah di Tengah Hoax." Rohani 03, Th. ke-64, (Maret 2017): 38-40.

Roekel, Dennis van. "Global Competence Is a 21st Century Imperative." NEA Education Policy and Practice Department (2010): 1-4.

Rohman, Saifur. "Masa Depan Intoleransi." Kompas, 23 Juni 2018.

Sadarusalam, Bambang Wiji Asmoro, dan Khoirul Hasan. "Kontra Propaganda Badan Nasional Penanggulangan Terorisme dalam Menanggulangi Perkembangan Radikalisme di Indonesia." The Indonesian Journal of Politics and Policy 1, no. 1, (Januari 2019): 74-82.

Salgado, Susana. "Online Media Impact on Politics. Views on Post-Truth Politics and Post-Postmodernism." International Journal of Media \& Cultural Politics 14, no. 3, (2018): 317-331.

Sindhunata. "Memedi Sawah." Kompas, 23 Februari 2019.

Kambing Hitam: Teori Rene Girard. Jakarta: Gramedia, 2007.

Siroj, Said Aqil. "Kembali ke Literasi." Kompas, 3 Mei 2019.

Subhan SD., M. (2). "Master Manipulator." Kompas, 13 Oktober 2018.

(1). "Likuefaksi Politik." Kompas, 6 Oktober 2018.

Suiter, Jane. "Post-Truth Politics." Political Insight (December 2016): 25-27.
Susila, Sidharta. "Melumpuhkan Pendidikan dengan Hoaks." Kompas, 2 Mei 2019.

Syuhada, Kharisma Dhimas. "Etika Media di Era 'Post-Truth'." Jurnal Komunikasi Indonesia V, no. 1, (April 2017): 75-79.

Vanhoozer, Kevin J. Biblical Narrative in the Philosophy of Paul Ricoeur: A Study in Hermeneutics and Theology. Cambridge: Cambridge University Press, 1990.

Vasu, Norman, Benjamin Ang, Terri-AnneTeo, Shashi Jayakumar, Muhammad Faizal, dan Juhi Ahuja. Fake News: National Security in the Post-Truth Era. Policy Report January. Singapore: S. Rajaratnam School of International Studies and Nanyang Technological University, 2018.

Vogelmann, Frieder. "The Problem of PostTruth Rethinking the Relationship between Truth and Politics." BEHEMOTH A Journal on Civilisation 11, no. 2, (2018): 18-37.

Wahjudin, Lisdawati. "Radicalism Rising among Educated People." International Journal of Multicultural and Multireligious Understanding 6, no. 3, (February 2019): 62-65.

Wibowo, A. Setyo. "Media Sosial dan Mobokrasi." Basis 11-12, Tahun ke66, (2017): 2-3.

Widjanarko, Putut. "Media Sosial yang Beradab.” Tempo, 2-8 Januari 2017.

Ylä-Anttila, Tuukka. "Populist Knowledge: 'Post-truth' Repertoires of Contesting Epistemic Authorities." European Journal of Cultural and Political Sociology (2018): 1-30. 